DOI: https://doi.org/10.18485/25bghun.2021.ch11

\author{
KAPPANYOS ANDRÁS \\ Bölcsészettudományi Kutatóközpont, Irodalomtudományi Intézet
}

\title{
Milyen fordítástudomány?
}

\section{Összefoglaló}

A tanulmány arra tesz kísérletet, hogy felmérje a mai magyarországi fordítástudomány tájékozódási irányait. A jól ismert, erős alapokon nyugvó nyelvészeti fordítástudomány és a frissen megindult, útját kereső, intézményeit most alapító kulturális fordítástudomány mellett egy metafizikai alapú gondolkodásmódot is azonosít, és rámutat a különféle területek közötti átmenet és együttmüködés lehetőségeire. A dolgozat második fele a mai magyarországi irodalomelmélet egyik legfontosabb axiómáját, a nyelvi megelőzöttség elgondolását helyezi a fordítástudomány kontextusába. A fordításról való gondolkodást alapjaiban határozza meg a nyelvszemléletünk: hogy nyelv és valóság viszonyát „leképezésként” vagy „konstituálásként” fogjuk-e fel. Ennek jegyében a fordításról való gondolkodás két lehetséges útvonalát és azok következményeit vesszük szemügyre. Az egyik irány az eredeti referencia teljes, szennyezetlen rekonstrukciójára kíván törekedni, a másik az emberi közrehatás, az oksági elv és a történetiség kiiktatásával a nyelvi önmüködésben próbálja megragadni a fordítás lényegét. Úgy tűnik azonban, mindkét fajta esszencializmus szem elől téveszti a nyelv diszkurzív, önmagát alakító működését.

Kulcsszavak: fordítástudomány, kulturális kontextus, nyelvi materialitás, kulturális transzfer, formahüség.

A fordítástudomány fordításeseményekkel, azok kondícióival és következményeivel dolgozik. Fordításeseménynek tekinthető egy fordítás elkészülése, közreadása, befogadása, kritikája, a fordítás kapcsán meghozott döntés, a fordítás révén létrejövő belátás, a fordítás feltételrendszerét érintő kulturális változás és így tovább. A fordításesemények tudományos igényü (azaz adatolt, absztrakt, oksági elvü) vizsgálata azonban különböző perspektívákból 
történhet, melyekből tekintve ugyanaz az esemény különböző szemléleti horizontokon jelenik meg, és vizsgálata így sokféle, egymással gyakran nehezen összevethető eredményhez vezet. A fordításról való gondolkodás jelenlegi helyzetében - elsősorban Magyarországra vonatkoztatva, de a nemzetközi fejleményeket is szem előtt tartva - három ilyen tudományos perspektívát érdemes megkülönböztetnünk: a nyelvészetit, a kultúratudományit és a metafizikait.

A nyelvészeti fordítástudomány a fordításeseményre alapvetően kognitív adatok átkódolásaként tekint, amely a forrásnyelv és a célnyelv között megy végbe. Ez a mozzanat valóban minden interlingvális fordításban közös. A nyelvészként gondolkodó Roman Jakobson a következőképpen határolja el ezt a tartományt: „Az a feltételezés, hogy vannak szavakkal ki nem fejezhető vagy lefordíthatatlan megismerési adatok, önellentmondás lenne” (Jakobson 1969: 379), majd néhány bekezdéssel később ezt írja: „...a költészet, legyenek bár szabályai abszolútak vagy korlátozottak, meghatározás szerint lefordíthatatlan” (Jakobson 1969: 381). A kognitív adatok tartománya tehát korlátozás nélkül átkódolható, de ez az eljárás nem alkalmazható a szövegeknek azon tartományaira, amelyek poétikai funkciót müködtetnek, amelyeknek nem a kognitív közlés a célja. Ugyanerről a filozófusként gondolkozó Walter Benjamin így beszél: „Mert mit »mond« egy írásmü? Mit közöl? Nagyon keveset annak, aki érti” (Benjamin 1980: 71). És természetesen ideidézhetjük Robert Frost mondását is, amely szerint „Költészet az, ami elvész a fordításban” (Frost 1973: 159). A nyelvészeti fordítástudomány tehát annyiban vizsgálja a fordítást, amennyiben az nyelvi jelenségnek tekinthető, és az irodalmi fordítás ezt meghaladó müveletei iránt - egy közmondás hozzávetőleges kulturális ekvivalensének megkeresésétől a rímtechnikáig - kevés érdeklődést mutat.

A nyelvészeti fordítástudomány határait igen pontosan kijelöli a David Crystal által szerkesztett kézikönyv példája. Az „It rains cats and dogs” angol mondatnak háromféle fordítását különbözteti meg: „Ez kutyákat és macskákat esik” (szó szerinti fordítás); „Kutyák és macskák esnek” (szöveghű fordítás); végül 
„Cigánygyerekek potyognak az égből” (szabad fordítás) (Crystal 1998: 428). Nyilvánvaló, hogy kulturális szempontból az első két verzió sikertelen: ezekben az esetekben semmiféle megértés nem jön létre, az első magyar mondat grammatikailag is hibás (az esik nem tranzitív ige, nem lehet tárgya), a második csak egyszerüen értelmetlen (nincs kulturális referenciája), és csak a harmadik az, amelynél egyáltalán módunk van elgondolkodni az ekvivalencián. Fogalmazhatnánk úgy, hogy a kulturális fordítástudomány vizsgálati területe ott kezdődik, ahol a nyelvészeti fordítástudományé véget ér - ez azonban nem volna teljesen igaz, hiszen a nyelvészek által vizsgált átkódolási műveletek valamennyi interlingvális fordítási vállalkozásnak részét képezik. A két terület közötti viszonyt egy korábbi írásomban a szervetlen és szerves kémia viszonyához hasonlítottam. (Kappanyos 2015: 24).

A nyelvészeti fordítástudomány Magyarországon teljességgel elismert tudományszak, az alkalmazott nyelvészet egyik legélénkebb területe, amely többszintű képzési rendszerrel, doktori iskolával, nemzetközileg jegyzett szakfolyóiratokkal rendelkezik. A kulturális fordítástudomány ehhez képest erős hátrányban van, hiszen a kultúratudomány (cultural studies) is csak a legutóbbi időkben kezdte kijelölni a maga határait, megteremteni az intézményeit szervezeti értelemben és művelői személyét tekintve is összekapcsolódva az irodalomtudománnyal. A kulturális fordítástudomány kutatói rendszerint a fordítás iránt érdeklődő irodalomtudósok, modern filológusok, komparatisták közül kerülnek ki. A hazai közegben ezek a kutatások egyrészt a müfordítói műhelytanulmányokat, másrészt irodalomtörténeti munkákat, első helyen talán Rába Györgynek a Nyugat versfordító hagyományát feltáró nevezetes monográfiáját (Rába 1969) tekinthetik hátterüknek. A közelmúlt erőfeszítései (mint a szöveggyüjteményeket és monográfiákat is közreadó remek Pont fordítva sorozat) ellenére igen jelentős a lemaradás, és nemcsak a nyugati mintákhoz, hanem például Szlovákiához képest is, ahol olyan munkák készültek el, mint a huszadik századi müfordítók két kötetes szótára (Kovačičova-Kusá 2015). 
Metafizikai fordítástudomány önálló diszciplínaként természetesen nem létezik, és ebben a formában nem is életszerü a megalapítása, ugyanakkor a szubjektum és nyelv viszonyát, a megértés mechanizmusait vagy a müalkotás létmódját firtató filozófiai diskurzusokban újra és újra szóba kerül a fordítás, mint egyes gondolatkísérletek laboratóriumi terepe, vagy adott esetben a vázolt koncepció próbaköve. A filozófusok kijelentései az absztrakciónak meröben más szintjén keresik érvényességüket, mint a nyelv valós, hétköznapi müködését vagy a kulturális praxisokat vizsgáló gondolatmenetek, de ez nem áll útjában az applikációs próbálkozásoknak. Walter Benjamin híres esszéje - eredetileg a saját Baudelaire-fordításaihoz írt előszó (Baudelaire 1923) - szinte alig tartalmaz a müfordító gyakorlati munkáját érintő tanácsokat, hiszen központi tárgya az irodalmi műalkotás létmódja és a műfordítás ebből való részesülése; a fordítói praxissal mint valamiféle értelemközvetítéssel való kapcsolatot (a befogadó figyelembe vételét) már az első mondat kizárja. A szöveg ennek ellenére (vagy bizonyos tekintetben éppen ezért, a praxissal szembeni már-már éteri távolságtartása miatt) olyan tekintéllyel rendelkezik, amely a mégoly praktikus célú fordítástudományi gondolatmenetek számára is megkerülhetetlenné teszi. Ilyen módon tehát a merőben elméleti konstrukció a módszertani segédlet szerepébe sodródhat, ami félreértésekhez, önellentmondásokhoz vezet. Máskor az egyes horizontokon létrejövő belátások olyankor is elkerülik egymást, amikor termékeny lenne a találkozás. Gadamer ezt írja például: „Minden fordítás, amely komolyan veszi a feladatát, világosabb és laposabb, mint az eredeti" (Gadamer 1984: 271). Olyasmit állapít meg tehát kvázi-elöíró modalitással, amihez a korpuszkutató nyelvészek merőben más úton, empirikus eszközökkel és leíró modalitásban jutottak el: az explicitáció, a szimplifikáció és a normalizáció a legalapvetőbb fordítási univerzálék közé tartozik (Malmkjær 2011).

A mai magyarországi irodalomelmélet egyik legalapvetőbb axiómája a nyelvi megelözöttség Humboldtig visszavezethető elgondolása. A koncepciót legtöbbször „tapasztalatként” említik, amely ilyenformán objektivitást nyer és nem is kíván bizonyítást - bár hogy milyen módon is kellene megtapasztalni, és 
hogy korábban miért nem tapasztalták, az nem egészen világos. Az immár világnézeti elemként alkalmazott elgondolás formája bizonyos szemszögből fedésbe hozható azzal, amire Wittgenstein episztemológiai szempontból jut el: „Nyelvem határai világom határát jelentik” (Wittgenstein 1989: 70); vagy amibe Derrida provokációja keveri félreértőinek hadát: „szövegen kívüli jelentés nincsen" (Derrida 2014: 18); és végsősoron valami egészen hasonló sejtelem rejlik a Sapir-Whorf-hipotézisben is, azzal a különbséggel, hogy ott nem általában a nyelvröl van szó, hanem éppen az egyes nyelvek kondíciókészletei közötti látványos különbségröl. Mindenesetre a gondolat mélyén annak belátása rejlik, hogy a nyelv nem „leképez”, hanem „konstituál”, megelőzi a valóságot, ahogyan azt János evangéliumának nyitó szavai is sugallják. Ebből további nagy horderejü belátások következnek, sok egyéb mellett a 20. századi magyar irodalom történeti szakaszolására és kanonikus elrendezésére nézve.

A fordítás problémája azonban nehezen kezelhető ebben a konstrukcióban. Ha a nyelv funkciója valamely nyelv elötti értelem vagy valóságvonatkozás leképezése volna, akkor az idegen szöveg lefordításának feladatát modellezhetnénk úgy, mint az adott értelem vagy valóságvonatkozás visszakeresését és másik nyelvben végbevitt leképezését, illetve egy mérsékeltebb verzióban mint az adott nyelvi konstrukció másodlagos leképezését, egy hozzá tartozó sajátos metatextus elkészítését (James T. Holmes a lefordított verset metapoem-nek nevezi (Holmes 1988)). Ha viszont az elénk kerülő idegen szöveg az idegen forrásnyelv által létrehozott konstrukció, akkor a fordítás során a célnyelvnek önmagából kell létrehoznia az új konstrukciót, amelynek az eredeti szöveggel való viszonya így tisztázatlan és esetleges: nehéz elgondolni, milyen erők szabályozzák, hogy a fordítás hasonlítson az eredetijére, és hogy ezt milyen mértékben, szervezettségének mely szintjén vagy szintjein tegye. Benjamin esszéje erre a problémára kínál metafizikai választ: az eredeti költemény voltaképpen nem más, mint önnön platóni ideájának partikuláris konkretizációja. Az ideális költemény a Bábel előtti „tiszta nyelven” (reine Sprache) (Benjamin 1980: 77) létezik, amelyet a halandók véges elméje természetesen nem érhet el, 
de minden fordítás közelebb visz ehhez a tökéletességhez. A sokat idézett cseréphasonlat arra utal, ahogyan a költemény partikuláris megtestesüléseiböl (amelyeknek a fordítások mellett csak egyike az eredeti szöveg) fokozatosan, végtelen közelítésben összeáll a mü kiteljesült, de immár nem emberi szemeknek és füleknek szánt végső alakja.

Benjamin azt nem tisztázza pontosan, milyen erő irányítja a fordítás folyamatát, mi gondoskodik róla, hogy a cserepek illeszkedjenek. Ez az erő lehetne a felsőbb hatalom figyelme, vagy a fordítókba táplált ihlet, de leginkább talán a nyelv(ek) struktúrájába rejtett mechanizmusok felelősek: a nyelvek „rokonok egymással abban, amit mondani akarnak.” (Benjamin 1980: 75). Arra nem tér ki, hogy maguk a fordítók mit tehetnek, hogyan lehetnek jobbak, de azt több helyen is megemlíti, hogy a rossz fordítók a hibás eljárásaikkal és téves előfeltevéseikkel tönkre tehetik az eredményt. Talán jobban értjük az intenciót, ha eredeti környezetében, a Tableaux Parisiennes kétnyelvü kiadásának előszavaként értelmezzük az írást: Benjamin voltaképpen apológiát ír, azt közli olvasóival, hogy a könyv valójában nem nekik készült, hanem sajátos imádság vagy áldozat, amelyet Baudelaire-rel együtt terjeszt az Úr elé. Ez a gesztus önmagában is megindító volna, ám közben maga az írás olyan gondolati és nyelvi intenzitást sugároz, hogy száz év elteltével is segít elrendeznünk azokat az ajánlatokat, amelyek a mai Magyarországon a fordításról való gondolkodást érintik.

A következőkben két olyan ajánlatot mutatok be, amelyek az utóbbi években érkeztek, és befolyásolhatják a fordításról való gondolkodás magyarországi kereteit. Az egyik ezek közül szinte szó szerint követi Benjamin útmutatását, a másik úgy bánik vele, mint Baradlay Kazimírné a férje végakaratával: mindenben épp az ellenkezőjére törekszik. Nézzük előbb az utóbbit.

Nádasdy Ádám, aki költőként, nyelvészként, tudománynépszerüsítőként már korábban is tekintélyes rangra és ismertségre tett szert, az ezredfordulót megelőző években jelentős fordítói vállalkozások sorába kezdett, amelyek egyéb, vitathatatlan eredmények mellett a magyar müfordításirodalom két legmagasabb 
presztízsű életművének, illetve ezen életművek „koronaékszereinek” revízióját, vagyis részleges leváltását indítványozták, és - legalábbis egyes használati módokra vonatkozóan - sikeresen meg is kezdték. Az új fordítások körül kialakuló viták rámutattak arra, hogy a nyelvi avulásnak még Arany János Shakespeare-fordításai sem tudnak a végtelenségig ellenállni, Babits Mihály Dante-fordítása pedig egy olyan müfordítói hagyományba illeszkedik, amely sem az eredeti mű intencióival, sem a mi korunk elvárásaival nem kompatibilis teljes mértékben. Nádasdy Ádám kiemelkedő érdeme, hogy ezeket a szakmai kérdéseket „médiaérzékennyé” tette, beemelte a müvelt laikusok közbeszédébe ugyanakkor van abban némi méltánytalanság, hogy ez a közfigyelem nem terjedt ki a közelmúlt más, szintén jelentős Shakespeare- és Dante-újrafordításaira, nem is beszélve itt a többi párhuzamos vállalkozásról. (Lásd egyebek mellett Baranyi Ferenc és Simon Gyula teljes, de még csak külön részekben kiadott Isteni színjáték fordítását, Jánosházy György és Mészöly Dezső Shakespeare-köteteit, Eörsi István, Forgách András, Varró Dániel Shakespeare-újrafordításait.)

Nádasdy Shakespeare-újrafordításaiban a szókincs modernizálása volt a legfontosabb nóvum, emellett azokat az Aranytól származó frazémákat sem tartotta meg, amelyek szokásmondásként beépültek a nyelvhasználatba („helyes a bőgés”, „ide nekem az oroszlánt is” stb.) A Dante-fordítás tovább megy ennél: a pontosság és világosság érdekében az eredeti legszembeötlőbb poétikai megoldásáról, a rímelésről is lemond. Döntését úgy magyarázza, hogy az eredeti könnyed, magától értetődő, népies hangütésü, az értelmet alig befolyásoló rímelését úgysem lehetne magyarul visszaadni, a keresett, „nyugatos” rímelés pedig megengedhetetlen mértékben torzítaná mind a referenciális jelentést, mind a stilisztikai regisztert - s másfelöl, hozzátehetnénk, ennek megkísérlése Babits erőfeszítését ismételné meg, vállalva a módszer veszélyeit, de nem garantálva az eredményeit (Nádasdy 2015). Az érvelés és a végkimenetel meggyőző, a létrejött szöveg egyértelmüen a magyar kultúra nyeresége. A Babits-szöveg által betöltött funkciók némelyikét elhárítja magától, miközben más funkciókat lényegesen jobban teljesít. 
A 2010-es években Nádasdy a forma elvetését mint „metódust” a lírai költemények fordítására is megkísérelte kiterjeszteni. Elöbb Keats Ode on a Grecian Urn címü költeményét fordította le rímtelen jambusban (Nádasdy 2014), majd Verlaine művét, a Chanson d'automne-t alakította sorokba tördelt prózává, illetve saját minősítése szerint szabadverssé (Nádasdy 2018a). Az utóbbi komoly vitát váltott ki, amelyben magam is részt vettem (Kappanyos 2018a, b), ezért nem is ismétlem az elhangzott érveket, csupán a jelen kontextus sajátos szempontjából szeretném megvilágítani, minek is lehetünk itt tanúi. Walter Benjamin pontosan leírja a Nádasdy Ádám által követett eljárást: ,az a fordítás, amely közvetíteni akar, egyebet se közvetíthetne, csak a közlendőt - tehát a lényegtelenséget" (Benjamin 1980: 71). Nádasdy szerint: „a müfordítás feladata - versek esetében is! - elsősorban az eredeti szöveg tartalmának hủ tolmácsolása" (Nádasdy 2018a: 280). Ennek megfelelően körültekintően közvetíti az eredeti vers közlendöjét: ősszel rossz az idő, és ez elmélyíti a depressziót. A magyar szöveg mintegy visszakeresi az őszi rosszkedv eredeti referenciáját, és leképezi azt - ám ez merőben érdektelen. Ami e százötven év előtti időjárás- és hangulatjelentésből a külső benyomások és a belső érzetek kölcsönviszonyára vonatkozó belátás vagy a nyelvet megelőző valóságreferencia, az minden mérsékelt égövön élő ember számára a legbanálisabb közhely - azokat is beleértve, akik sosem hallottak Verlaine-ről. Érdekessé mindez attól vált, hogy bonyolult és kifinomult, gazdagon rétegzett nyelvi formát talált: dal lett belöle, amelyet a formája emel ki a hétköznapok esetlegességéből és banalitásából. Olyan dal lett, amely ennek a közhelyes benyomás-reflexió komplexumnak az egyetemes formájává tudott válni. A mü létezésének az eredetiben sincs más értelme, mint ez a formaadás: ha Verlaine prózában mondta volna el ugyanezt a „mondanivalót” (mint ahogy magánbeszédben néhányszor bizonyára el is mondta, mint úgyszólván bárki más), azt ő maga sem tartotta volna feljegyzésre érdemesnek, tehát a fordítás igénye fel sem merült volna, hiszen ez esetben az egész megnyilvánulás megmaradt volna a partikularitás, a banalitás, a hétköznapiság tartományában. 
Ami a drámai és epikai nagyformában müködik, az a lírában csődöt mond: a nagyforma a strukturáltsága révén (amelynek számos fontos aspektusát a pontos prózai fordítás is átviszi) jótállhat magáért, képes lehet betölteni az elvárt kulturális funkciók szignifikáns részét. A kis terjedelmü lírai szöveg - különösen az ilyen dalszerü, amelyet éppen a forma és csak a forma emel ki a köznapi beszédből - formájától megfosztva elveszti legitimációját, motivációját: érthetetlenné válik, mivégre mondja ezt valaki, mivégre van mondva. Az ilyen szöveg csak a kontextustól nyerheti vissza az értelmét, például ha az eredeti szöveg mellett áll magyarázó nyersfordításként vagy akár alaposan kidolgozott tanári-tudósi fordításként, de ez nyilvánvalóan nem az autonóm müalkotás pozíciója. A másik lehetőség, ha egy nagyobb korpusz részeként jelenik meg, s e nagyobb korpusz (például egy Verlaine-ciklus) megteremti a saját nyelvi univerzumát, konstituálja a saját beszélőjét, kivívja a saját autonómiáját, amelyböl ezután az egyedi szöveg is részesül.

Megítélésem szerint a kezdeményezés a lírafordítás tekintetében nem vezetett sikerre, ezért kissé elsietettnek látom Körizs Imre megállapítását, aki szerint - bár a szövegszerü eredménnyel ő sem elégedett - „száz év múltán először van komolyan vehető kihívója a klasszikus magyar versfordítói hagyománynak" (Körizs 2020: 373). Nem vagyok benne biztos, hogy ennek a hagyománynak valóban ilyen radikális kihívásokra van szüksége, különösen azért, mert magukra a müfordítókra sohasem volt jellemző az ájult tekintélytisztelet. A kanonizált fordítás „leváltása” mindig vonzó feladat volt, és olykor sikerült is; a hagyomány folyamatosan meg tudta újítani magát, és ehhez nem kellett radikális táblaborogatás. A rossz beidegződések kritikájára persze nagyon nagy szükség van (a prózafordításban is), de a hagyományosan magas színvonalú magyar müfordításkultúra javát talán az szolgálná legjobban, ha sok tehetséges, felkészült fordító jelentkezne új fordításokkal és újrafordításokkal, ha lenne hely a képzésükre és versengésükre, és ha több fórum lenne ezeknek a munkáknak a megmutatására és megvitatására. 
Nádasdy Ádám javaslata tehát kifejezetten a kulturális praxisra irányul, de magát a transzferáló aktivitást a nyelvtudományi szemlélet által belátható terepen belül maradva képzeli el, vagyis a szemantika, a szintaxis, továbbá a stilisztikai regiszter megfeleltetését tartaná szükségesnek (kezdeményezésének egyik inspirációja az a megfigyelés, hogy a verstani forma egyeztetése feldúlja az eredeti szintaxist, holott az sem lényegtelenebb, mint a versforma - lásd a korábban említett vita dokumentumait). A másik javaslat nem jut ennyire közel a gyakorlathoz, mivel legfontosabb előzetes müveletként éppen a kulturális praxis szempontjainak teljes kiiktatását végzi el. Mezei Gábor könyvvé formált doktori disszertációjáról van szó, amely arra vállalkozik, hogy megkeresse Walter Benjamin gondolatmenetének hiányzó láncszemét, és választ adjon arra, mi szabályozza a cserépdarabok pontos illeszkedését (Mezei 2016). Szerinte a felelet a nyelv materialitásában rejlik, vagyis a nyelvi megelőzöttség egy olyan aspektusában, amelyre a nyelvet használó szubjektumnak (szerzőnek, fordítónak, befogadónak) végképp semmiféle ráhatása nincs, amely egyszerüen „úgy van”.

Mezei Gábor ehhez alaposan megtisztítja maga előtt a terepet. Bevezetőjében a kortárs fordítástudomány teljes mezőnyét elutasítja, Susan Bassnettől Lawrence Venutin át Emily Apterig és Rába Györgytől (megtisztelő módon) az én nagydoktori disszertációmig (Mezei 2016: 11, 14), voltaképpen egyedül Walter Benjamin esszéje marad állva. Ezután kizár a fordítás vizsgálatából minden olyasmit, ami valamiképpen emberi döntésekhez vagy a fordításesemény kulturális kondícióihoz lenne köthetö. Kiiktatja az ágenciát, vagyis a fordításnak egy szubjektum közrehatásához kötött elképzelését; az idegen-saját relációt, vagyis a müvelet kulturális transzferként való elképzelését; szemantikai hasonlóságok, metaforikus megfelelések vagy helyettesítések (illetve az ezekre való törekvés) tételezését a forrás- és fordításszöveg között; továbbá a két szöveg történeti beágyazottságának, illetve kölcsönös történeti viszonyának figyelembevételét (a fordításszövegnek a forrásszöveg általi megelőzöttségét). Így nem marad más, mint a cserepek illesztgetése, pontosabban inkább illeszkedésük vizsgálata, hiszen immár „...nem »emberi eseményként« 
tételeződik a fordítás folyamata, hanem éppen a korábban szóba hozott nyelvi anyagisághoz köthető önmüködésre helyeződik a hangsúly" (Mezei 2016: 12). A fordítást nem úgy kell elképzelnünk, hogy a fordító egy eredeti alapján, saját véges kompetenciáira támaszkodva, nyelvi átkódoló és kulturális leképező müveletek segítségével létrehoz egy fordítást, hanem úgy, hogy két egyenrangú szöveg „fordításviszonyt létesít”.

A gondolatkísérlet bátorsága, következetessége és kidolgozottsága elismerésre méltó, de az eredmény arra figyelmeztet, hogy ne értsük félre a saját premisszáinkat (vagy dogmáinkat). A nyelvi megelőzöttség nem azt jelenti, hogy a nyelv csinálja a valóságot (bár bizonyos konstellációkban természetesen csinál is valóságot), hanem elsősorban azt, hogy a nyelv meghatározza, mit tudunk kezdeni a valósággal, vagy hogy mely részleteivel tudunk egyáltalán valamit kezdeni. Másképpen mondva: a nyelv meghatározza, hogy mit lehet mondanunk, vagy hogy egy adott közlésben mit nem lehet elhallgatnunk, de nem mondja meg, hogy mit mondjunk. Az még sohasem fordult elö, hogy a nyelv magától lefordított vagy megírt volna valamit, mint ahogyan a téglák és gerendák sem tudnak házat építeni, noha természetesen erősen behatárolják, hogy milyen ház építhető belölük. A nyelv beszél, de vajon akkor is beszél, ha senki nem hallgatja?

Nézzünk egy példát. A könyv egyik elemzése Shakespeare 15. szonettjét és annak Szabó Lőrinc által készített fordítását veti össze, kiiktatva a müveletből a szubjektum és a történeti vagy kulturális beágyazottság mindenféle közrehatását. A szonett mindkét verziója az emberi és a növényi élet allegorikus egymásra vetítésével játszik el, de zárlatuk radikálisan eltér. Míg Shakespeare szonettje végén az „I engraft you new” (“újjá oltalak’), Szabó Lőrinc verziója végén a „feltámasztalak” kijelentés áll. Ez utóbbi a megszólított már bekövetkezett halálát feltételezi, míg az előbbi nem utal ilyesmire. A két, kétségkívül jelentős szemantikai eltérést mutató szöveg közötti, benjamini értelemben vett érintkezést Mezei Gábor azáltal látja biztosítottnak (vagy motiváltnak), hogy az angol szövegben három sorral korábban szereplö debateth (Szabó Lörincnél 'küzd') ige hypogrammaként tartalmazza a death ('halál') névszót (Mezei 2016: 50). 
Természetesen felesleges megkérdezni, hogy került ez oda: ezt a nyelv materialitása teszi. A kérdés inkább az, hogyan kerül ki onnan; miért épp ez szólal meg, s nem a többi lehetséges hypogrammák - debt, date, bat, bate, bath, eat, ate - valamelyike, vagy a szonett többi szavából százszámra kibányászható, semmivel sem kevésbé kézenfekvő kabbalisztikus üzenetek. Ha ezt a döntést maga a nyelv hozná meg, akkor nem lenne szükség a „felfedezésre”: mindenki előtt napnál világosabban állna ez a jelenlét. A death jelsort vagy egy szubjektumnak kell kiválasztania (és e ponton mindegy, hogy ez Mezei Gábor vagy Szabó Lörinc), vagy az intentio operisböl kell következnie, mely esetben az eredeti és fordítás közötti szemantikai kongruencia nyer bizonyítást, és a beíródás merö redundanciává válik. A nyelv egyedül nem tudja ezt elintézni.

Occam borotvája arra késztet, próbáljuk meg rekonstruálni a fordítói döntés körülményeit. Nincs okunk kétségbe vonni, hogy Szabó Lőrinc pontosan megértette az „I engraft you new” kifejezés értelmét: a gyümölcsfáknál használatos megújító, fiatalító metszésről, illetve oltásról van szó. Azt is pontosan felmérte azonban, hogy míg Shakespeare idején ez a müvelet általános tudásnak számított (nem lehetetlen, hogy saját stratfordi kertjében a költő maga végezte a müveletet), a huszadik századra egy specifikus szaktudás körébe húzódott vissza. Megnevezése így a hétköznapi (városi) köznyelvböl is kiszorult, helyébe ugyanakkor benyomult az oltás szó orvosi értelme. Ha Szabó Lőrinc a húszas évek legelején azt írta volna a vers zárlatába, hogy „újjá oltalak” (vagy még inkább „metszelek”), ami egyébként semmiféle verstani-prozódiai akadályba nem ütközött, akkor a kortárs olvasóknak minden bizonnyal valamiféle orvosi eljárás, mindenekelött az akkoriban népszerü Steinach-féle fiatalító mütét jutott volna az eszükbe. Ebben az esetben a nyelvi megelőzöttség ezen a sajátos módon müködött: Arany János még fordíthatta volna a zárlatot a kertészeti szakkifejezéssel, de Szabó Lőrincnek ez már nem állt módjában, mert a valóságban végbement változások szétzilálták a kifejezés referenciáit. A fordító minden bizonnyal éppen a potenciális befogadók érdekét szem elött tartva távolodott el a mezőgazdasági müvelet konkrét, és az aktuális konnotációk miatt 
súlyosan félreérthető megnevezésétől egy absztraktabb (kényszer)megoldás irányába. Egy esetleges mai fordító még nehezebb helyzetben lenne, hiszen az olt ige időközben a 'cinkel, cikiz, kihívóan gúnyol' jelentéseket is felvette.

Méltánytalan volna, ha ezt a két radikálisan szemben álló, de egyaránt színvonalas, a fordításról való gondolkodás megváltoztatását célzó javaslatot egyoldalúan diszkreditálni próbálnám. Vitatkozni feltétlenül érdemes velük, mert a megcsontosodott gondolkodási mechanizmusok kizökkentésével új belátásokat nyitnak meg; végeredményben azonban a dominánsan érvényben lévő versfordítói gyakorlathoz képest, úgy vélem, mindkettő reduktív. Az egyik az esztétikai funkció érvényesítését fogná vissza, a másik magát az eleven kulturális transzfert, s vele az emberi megértést, belátást, élményt, gyarapodást. A legérdekesebb, hogy e redukció paradox módon a saját gyakorlatukban is megmutatkozik. Nádasdy egyfelöl azt mondja, „a szépség létrehozása [...] túllép a fordítás megengedhető keretein" (Nádasdy 2018a: 280), másfelől saját szövegének versszerüsége mellett éppen azzal érvel, hogy külön munkát fektetett a szépségbe: „szerintem egész jó kis szabadvers, sokat csiszolgattam, mérlegeltem [...]” (Nádasdy 2018b: 407). A másik ajánlat hasonló belső ellentmondása nem Mezei Gábornál jelenik meg, hanem már Walter Benjaminnál. Első bekezdésében a fordítás lényegi funkciója szempontjából érdektelennek ítéli a befogadót nemcsak az „adott közönséget”, hanem a feltételezett „eszményi befogadót” is (Benjamin 1980: 71) -, de ezt épp annak a könyvnek a bevezetöjében teszi, amelyben közreadja Baudelaire-fordításait - olvasóként pedig (a szakértők szük körén kívül) ki másra számíthatna, mint német emberekre, akik történetesen nem tudnak franciául.

\section{Bibliográfia}

Baudelaire, Charles 1923. Tableaux parisiens. Deuche Übertragung mit einem Vorwort über die Aufgabe des Übersetzers von Walter Benjamin. Heidelberg: Verlag von Richadr Weissbach. 
Benjamin, Walter 1980. A műfordító feladata. In: Angelus Novus. Budapest: Magyar Helikon. 69-86. Ford. Tandori Dezsö.

Crystal, David 1998. A nyelv enciklopédiája. Budapest: Osiris Kiadó. Ford. munkaközösség.

Derrida, Jacques 2014. Grammatológia. Budapest: Typotex Kiadó. Ford. Marsó Paula.

Frost, Robert 1973. Conversations on the Craft of Poetry. (ed.) Elaine Berry. New Brunswick: Rutgers University Press.

Gadamer, Hans-Georg 1984. Igazság és módszer. Egy filozófiai hermeneutika vázlata. Budapest: Gondolat Kiadó. Ford. Bonyhai Gábor.

Holmes, James S. 1988. Poem and Metapoem: Poetry from Dutch to English. In: Translated! Papers on Literary Translation and Translation Studies. Amsterdam: Rodopi. 9-22.

Jakobson, Roman 1969. Fordítás és nyelvészet. In: Hang-jel-vers. Budapest: Gondolat. 372-382. Ford. munkaközösség.

Kappanyos András 2015. Bajuszbögre, lefordítatlan. Műfordítás, adaptáció, kulturális transzfer. Budapest: Balassi Kiadó.

Kappanyos András 2018a. Szellem a dobozban. Jelenkor 61., 3. sz. 282-287.

Kappanyos András 2018b. Szép hütlenek és derék tramplik Jelenkor 61., 7-8. sz. 883887.

Kovačičová, Ol'ga, Kusá, Mária (eds.) 2015. Slovník slovenských prekladatel’ov umeleckej literatúry 20. storočie. Bratislava: VEDA, Ústav svetovej literatúry SAV.

Kőrizs Imre 2020. Csak zenét ne. Kísérlet a magyar versfordítás megújítására. In: Fazekas Csaba szerk. Bonarum Cultores Artium. A Miskolci Egyetem Bölcsészettudományi Karának kutatói almanachja. Miskolc: Miskolci Egyetem BTK Alkalmazott Társadalomtudományok Intézete. https://www.unimiskolc.hu/ btmtt/almanach/365-373.pdf (utolsó megtekintés: 2020. 03. 20.)

Malmkjær, Kristen 2011. Translation universals. In: Kristen Malmkjær, Kevin Windle eds. The Oxford Handbook of Translation Studies, Oxford: Oxford University Press. 83-93.

Mezei Gábor 2016. Fordítás és anyagiság. Az írás mint kultúrtechnika az Örök barátainkban. Budapest: Ráció Kiadó.

Nádasdy Ádám 2014. John Keats: Óda egy görög vázáról. Bárka Online. június 23., http://www.barkaonline.hu/uzenet-a-palackban/4100-uezenet-a-palackban-40 (utolsó megtekintés: 2020. 03. 20.)

Nádasdy Ádám 2015. A rímelés veszélyei. Élet és irodalom 59., 24. sz. 13.

Nádasdy Ádám 2018a. Az ősz hegedűi (Verlaine Öszi dala és magyar fordításai). Jelenkor 61., 3. sz. 273-281.

Nádasdy Ádám 2018b. Gombhoz a kabátot. Jelenkor 61., 4. sz. 406-408. 
Rába György 1969. A szép hütlenek. Babits, Kosztolányi, Tóth Árpád versfordításai. Budapest: Akadémiai Kiadó.

Wittgenstein, Ludwig 1989. Logikai-filozófiai értekezés. Budapest: Akadémiai Kiadó. Ford. Márkus György. 


\title{
What Sort of Translation Studies?
}

András Kappanyos, Research Centre for the Humanities, Institute for Literary Studies

\begin{abstract}
This paper attempts to assess the directions of translation studies in today's Hungary. In addition to well-established linguistic translation studies and the relatively newly launched cultural translation studies establishing its institutions these days, we can also identify a metaphysically based mindset. We try to point out some opportunities for transition and cooperation between these areas. The second half of the paper puts one of the most important axioms of contemporary Hungarian literary theory, the idea of linguistic precedence or priority, in the context of translation studies. Our theorizing of translation is fundamentally determined by our approach of language: whether we see the relationship between language and reality as "imaging" or "constituting". Accordingly, we look at two possible current ways of thinking about translation and their consequences. One direction seeks a complete, uncontaminated reconstruction of the original reference, while the other seeks to capture the essence of translation in linguistic automatisms by eliminating human contribution, causality, and history. However, both types of essentialism seem to lose sight of the discursive, self-shaping function of language.
\end{abstract}

Keywords: translation studies, cultural context, linguistic materiality, cultural transfer, prosodic fidelity.

\section{Kakva nauka o prevođenju?}

Andraš Kapanjoš, Centar za humanistička istraživanja, Institut za književnost

\section{Sažetak}

Ovaj rad nastoji da proceni pravce translatoloških studija u savremenoj Mađarskoj. Uz dobro utemeljene lingvističke studije traduktologije i relativno nedavno osnovane studije kulturoloških pravaca translatologije, možemo da identifikujemo pristup baziran na metafizici. Želimo da predočimo neke od prilika za transfer i saradnju među ovim oblastima. Drugi deo rada se bavi jednim od najvažnijih aksioma savremene mađarske književne teorije, idejom ,jezičkog prethođenja”, u kontekstu studija prevođenja. Naše teoretisanje o prevodu je fundamentalno određeno načinom na koji pristupamo jeziku: u zavisnosti od toga da li odnos između jezika i stvarnosti vidimo kao ,preslikavanje” ili „građenje”. U skladu s tim gledamo na moguća dva savremena pravca razmišljanja o prevodima i njihovim uticajima. Jedan pravac traži potpunu, neukaljanu rekonstrukciju originala, a drugi se trudi da sagleda suštinu prevođenja u lingvističkom automatizmu, eliminišući ljudske doprinose, kauzalnost $\mathrm{i}$ istoriju. Ipak, oba tipa esencijalizma gube diskurzivnu, samooblikujuću funkciju jezika iz vida.

Ključne reči: translatološke studije, kulturni kontekst, lingvistička materijalnost, kulturni transfer, prozodijska vernost. 